\title{
SOCIAL COHESION IN EDUCATION: COGNITIVE RESEARCH IN THE UNIVERSITY COMMUNITY
}

\footnotetext{
Dr. Marja Nesterova, Faculty of Management of Education and Science, National Pedagogical Dragomanov University, Kyiv, Ukraine

E-mail: marja@nesterova.com.ua

Dr. Maryna Dielini, Faculty of Management of Education and Science, National Pedagogical Dragomanov University, Kyiv, Ukraine

E-mail:m.dielini@gmail.com

Dr. Andrii Zamozhskyi, Faculty of Management of Education and Science, National Pedagogical Dragomanov University, Kyiv, Ukraine

E-mail: reezo@gmail.com

\section{A R T I C LE IN F O}

Original Research

Received: July, 19.2019.

Revised: August, 12.2019.

Accepted: August, 17.2019.

doi:10.5937/IJCRSEE1902019N

UDK

$316.472 .4: 378.4(477)$

159.923.5.075:378.4(477)

Keywords:

cognitive research,

education,

social cohesion,

social cohesion model,

university community.

\begin{abstract}
A B S T R A C T
The present article highlights the results of social cohesion study fulfilled in the university community of National Pedagogical Dragomanov University. It contains the consideration of social cohesion as an important factor of interpersonal communication, other social skills which are important for the community development. The purpose of the study was to identify the level of social cohesion for university community, to test the Bertelsmann Stiftung Model of Social Cohesion at the community level. Methods that were used in the study are synthesis, analysis, math, social questionnaire, etc. In the research the only data collection tool was the author's questionnaire. There were 112 people interviewed, among them 47 employees and 65 students of National Pedagogical Dragomanov University. According to the study results, the level of social cohesion in the university community is quite sufficient, which positively characterizes the attitude of employees and students to each other, reflects their readiness for mutual respect and support, acceptance of differences and tolerance etc. Also the research highlights weak points of social interactions that form the base for further
\end{abstract} investigations and actions on social cohesion development.
}

(C) 2019 IJCRSEE. All rights reserved.

\section{INTRODUCTION}

Modern cognitive researches are turning to the actual social issues of society development. One of them is the social cohesion which allows to involve all social actors in the society development and complex social problem solving. These problems are social isolation, social disintegration, poverty, violence communication etc. (European Year for combating poverty and social exclusion, 2010). While the concept of social cohesion is rather new,

Corresponding Author

Dr. Marja Nesterova, Faculty of Management of Education and Science, National Pedagogical Dragomanov University, Kyiv, Ukraine

E-mail: marja@nesterova.com.ua

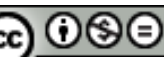

This work is licensed under a Creative Commons Attribution - NonCommercial - NoDerivs 4.0. The article is published with Open Access at www.ijcrsee.com since its basic principles were laid down only in 1990 within the framework of the Council of Europe, so there are many studies associated with it already: Social Cohesion Model, EU Social Cohesion Policy, Social Cohesion Radar etc. (Dragolov et al., 2013). We can discuss the cognitive aspects of this phenomenon and initiate the appropriate research because it covers many socially important issues simultaneously both on the individual and on the sub-individual (collective) levels of consciousness. The study of social cohesion is actual because it highlights very important problem of social areas, the "weak points" of social relations (Bondarenko, Babenko, Borovskyi, 2017). Cognitive mechanisms of social cohesion have neurobiological, evolutionary bases. Early in the human mankind's history there were some difficult periods when it was necessary to join each other for the surviving. These "rainy days" are happened quite often and periodically. Nowadays we are experiencing some kind of them - unpredictable and 
turbulent changes, financial and geopolitical crises etc.

The European Cohesion Policy is one of the answers to the challenges of the very fast changing modern society and it is deeply connected with European Education Police. Lisbon strategy claims that education could be considered as the one of the key forming factors of the European social model. Education and social cohesion are connected in several directions. One of them is educational strategies oriented onto the social cohesion development - practices of intercultural dialog, non-violence communication, common problem solving techniques etc. Also these are techniques of better teaching and learning to enhance the social intelligence of students (Nesterova, 2019). Another side of the social function of education is establishment of social connections, social networks which sufficiently impact on the personal development and social adaptability of persons.

According to the World Bank Report "Social Cohesion in Education" the respect of diversity and intercultural dialog skill are quite important. There is one of the definition of social cohesion as a "societal, not an individual, phenomenon that includes the level of trust and understanding of shared principles among groups in a society" (Roberts-Schweitzer, E., Greaney, V. and Duer, K. 2006). The social role of education in the increasing of social cohesion is lied on the respect for diversity and it was quite clearly shown at the world conferences: World Conference on Education for All in Thailand (1990), World Education Forum in Senegal (2000) etc. Other international conventions, such as the Universal Declaration of United Nations on Human Rights (1948) and the Convention of United Nations on the Rights of the Child (1989), also promote this link between education and tolerance for diversity (Roberts-Schweitzer, E., Greaney, V. and Duer, K. 2006). They claim that education should be leading tool of social cohesion development which allows to avoid social exclusion and inequality. Understanding of the social cohesion as a social phenomenon is quite important for further investigations in the sphere of cognitive approaches in education, in particular, in the direction of social dimensions of cognitivistics as a nonlinear complex of the human behavior and thinking, fundamental and applied cognitive researches (Nesterova, 2015). Social cohesion development is in the cross of economic and psychology problematics which impact on social behavior. Practices of intercultural dialog will help to reduce inequality between of members of one or more cultures (Nesterova, 2019), to improve the social cohesion, in particular the connectedness of educational communities.

We can maintain that the one of the main aspects of social role of education is social cohesion development. But at first it is necessary to determine this phenomenon. We can split off the social cohesion in separate features as tolerance, adaptivity to inequality, understanding etc. Thus, the model of social cohesion which will be described more properly below includes some cognitive parameters which are responsible for the social behavior. These parameters could be referred to social consciousness and social emotions. Synergetic approach claims that two independent parameters define the behavior of complex nonlinear system. Their dynamic balance could be the driver of its sustainable development (Nesterova, 2015). Emotional competence of individuals (which caused tolerance, adaptivity to various complex communication situations etc.) and social cohesion of social communities to be the parameters of this dynamic balance of sustainable society development.

Another social function of education is forming of values of new generation. It corresponds to the important demand of the society - common values platform for dialog, for social cohesion. In the education and other sphere of social innovations the significant space should be occupied by values as a driver of human behavior, impacting opinions, deeds and performance of an individual (Social Cohesion and Education). Some very substantial researches consider a social cohesion as a societal, not an individual, phenomenon that includes the level of trust and understanding of shared principles among groups in a society (Roberts-Schweitzer, E., Greaney, V. and Duer, K. 2006).

The role of social cohesion in education could be both positive and negative. The positive role of education in the development of social cohesion reflects in the understanding among people, reducing of violence in the educational dimensions etc. Obviously, in case of negative role of education (for instance, when it's not appropriately managed) it is fostering of economic, ethnic and other tensions (Roberts-Schweitzer, E., Greaney, V. and Duer, K. 2006). The key role of education in the social cohesion of communities is quite confident. Also educators have to be keepers and translators of the values, values of social cohesion in particular. So, this important task for educators to be translators of social co- 
hesion values could be realized only in connected educational communities with the sufficient level of social cohesion. Therefore, the further investigations of the various aspects of social cohesion in education (e.g. in educational communities) are very actual directions of the cognitive researches in social and educational spheres. For instance, the social activity of youth in the university community is the subject of cognitive research (Shamionov and Grigoryev, 2019). Other aspects of social behavior, cognitive patterns of social cohesion in education in wider social context are also the subjects of the higher education studies, i.e. university-community partnership (Sasson, 2018). The project INCLUD - ED financed by European Commission in the $6^{\text {th }}$ EU Working Program (2006-2011) was aimed to the practical aspects of social cohesion in education: social technologies and cognitive foundations of social cohesion in educational dimensions, in particular, in secondary schools (Alexiu, T. M. and Sordé, T., 2011). At the National Pedagogical Dragomanov University the authors developed the ideas of the INCLUD - ED and initiated some research projects which are implementing now. One of them is the project "Social Cohesion Development of Subjects of Educational Dimension", supported by Ministry of Education and Science in Ukraine (Prof. Marja Nesterova is leading expert and project manager). The project is oriented to the key stakeholders of secondary schools (more then 160) among all Ukraine. The social role of education is clearly reflected in the practical results of the project: all participants are noticing the real enhancement of quality of communication, tolerance, dialog skills etc. The obtained results were the foundations of further investigations in the field of social cohesion aspects in education. One of them is Jean Monnet Module "Social Cohesion in Education and Governance: European Studies" (SCEGES) which is implementing now at the
National Pedagogical Dragomanov University (academic coordinator Prof. Marja Nesterova). The SCEGES project also is oriented onto the practical issues of social cohesion in education, e.g. social cohesion development in educational communities. But the sentence "you cannot manage, if you cannot measure" is still actual. Therefore, the problem of evaluation of social cohesion level in the communities demands the proper solution.

\section{MATERIALS AND METHODS}

The authors use the Bertelsmann Stiftung approach for social cohesion's measurements. Originally the methodology of Bertelsmann Stiftung has been published at the report "The Social Cohesion Radar - An international Comparison of Social Cohesion" (2013). The report contains the evaluation of the social cohesion level in 34 advanced societies (27 member states of the European Union1 and seven other western OECD countries: Australia, Canada, Israel, New Zealand, Norway, Switzerland and the US) during four time periods from 1989. to 2012. This research has been created to measure social cohesion and its nine dimensions (Dragolov et al., 2013). The team of researchers from Jacobs University Bremen in Germany carried out the study belongs to a social reporting initiative of the Bertelsmann Foundation that aims to provide the general public with a conceptually and methodologically sound overview of the levels and trends of cohesion as well as an indepth understanding of its determinants and outcomes" (Dragolov et al., 2013).

The Model of Social Cohesion by Bertelsmann Stiftung consists of three domains of social cohesion and their respective dimensions. The description of this model is in Table 1. 2013)

Table 1. The dimensions of social cohesion and their guiding principles (Dragolov et al.,

\begin{tabular}{lll}
\hline Domain & Dimension & Guideline \\
\hline $\begin{array}{l}\text { Social } \\
\text { relations }\end{array}$ & $\begin{array}{l}\text { Social networks } \\
\text { Trust in people } \\
\text { Acceptance of } \\
\text { diversity }\end{array}$ & $\begin{array}{l}\text { People have strong, resilient social networks. } \\
\text { People have a high level of trust in others. } \\
\text { People accept others with the different lifestyles and values and lifestyles }\end{array}$ \\
\hline \multirow{2}{*}{$\begin{array}{l}\text { Connectedness } \\
\text { Trust in institutions }\end{array}$} & $\begin{array}{l}\text { People feel strongly connected to their country and identity with it. } \\
\text { People have a high level of confidence in social and political institutions. } \\
\text { People believe that society's goods are fairly distributed and that they are } \\
\text { being treated fairly. }\end{array}$ \\
\hline \multirow{2}{*}{$\begin{array}{l}\text { Focus on the } \\
\text { common good }\end{array}$} & $\begin{array}{l}\text { Solidarity and } \\
\text { helpfulness } \\
\text { Respect for social } \\
\text { rules } \\
\text { Civic participation }\end{array}$ & $\begin{array}{l}\text { People feel responsibility for others and are willing to help them. } \\
\text { People abide by the fundamental rules of society. }\end{array}$ \\
& $\begin{array}{l}\text { People participate in society and political life and enter into public } \\
\text { discussions. }\end{array}$ \\
\hline
\end{tabular}


It is important to notice that the Bertelsmann Stiftung's approach to measuring social cohesion is based only on secondary data analysis. This method reuses data already collected by researchers to answer similar or same research questions. The method is universally applicable and its application is expedient in social sciences. For example, Smith shows that $75 \%$ of articles related to empirical analysis in the three authoritative British sociological journals use secondary data (Smith, 2008).

This approach has been continued in the sociological research of scientists from Taras Shevchenko National University. They presented results of the research of social cohesion based on the secondary data from the sixth European Social Survey (Bondarenko, Babenko, Borovskiy, 2017). The explanation of the measurement of social cohesion as a social phenomenon due to paradigm shift in approaches to measuring the quality of life of societies is proposed. This involves consideration of social cohesion as a weighty factor for measuring the social quality of life. The method used by Bertelsmann Stiftung, which was tested on the available data of the European Social Survey of the Sixth Wave, which included Ukraine, was used for this, and was additionally certified through the analysis of other sources. The study made it possible to make a number of meaningful conclusions about the level of social cohesion in Ukraine compared to other European and world countries. The recommendations for further research of social cohesion are given.

We have analyzed the social cohesion of the representatives of university community of National Pedagogical Dragomanov University (NPDU): employees of NPDU (mostly lecturers) and students. The purpose of the study was to identify the level of social cohesion for university community, to test the Bertelsmann Stiftung social cohesion model for application at the community level, not the country.

As we described earlier the Bertelsmann Stiftung social cohesion model has the three main domains which are: social relations, connectedness and focus on the common good. These domains are divided into 3 dimensions and characterizes people for each of them. So "social relations" covers social networks, trust in people and acceptance of diversity. "Connectedness" comprises identification, trust in institutions and the perception of fairness. "Focus on the common good" covers solidarity and helpfulness, respect for social rules and civic participation. On the basis of this we have developed an author's survey method- ology, which gradually reveals each of these domains and dimensions. Each dimension is revealed by 3 questions, which in total are 27 questions in the questionnaire. The questionnaire is designed both for assessing social cohesion in society, and modified for the educational sphere. So, on the basis of the study of social relations and relationships within this framework, we have the opportunity to find out how strong the social connection is in the community in which the survey is conducted. In our case, it is employees and students of the National Pedagogical Dragomanov University (Kyiv, Ukraine). That is, two groups of people belonging to the same community. Also, within this domain, we can determine how much people trust each other and how individuals treat and accept individuals with different values/ views / lifestyles.

Through the study of connectedness, we obtain results that allow us to analyze how strong the relationship is with the educational community in general and at smaller levels, and to identify or identify the respondents themselves with their community. Determining the level of trust in the institutions is important in the determination of social cohesion, since trust reflects the attitude towards its institution. The greater the level of trust, the better the relation to your environment. The fair attitude to itself is appreciated in order to find out what is perceived attitude towards yourself in your environment.

Evaluating a sense of responsibility one by one makes it possible to see how closely connected a community is, how people understand that their actions have an impact on others and take it into account in their activity.

Respect and observance of norms and rules reflect behavior that is adequate to social norms and without deviant deviations, which ascertains the attitude and respect for their social community.

The degree of participation in social/ public and political life (Civic participation) depends on the social cohesion of both the individual and the collective as a whole. The greater the involvement in joint activities outside the working relationship, the greater the level of cohesion.

Twenty-seven questions of the questionnaire are evaluated on a scale of 1 to 5 , where 1 is low, 2 is below average, 3 is average, 4 is above average, 5 is high.

There were 112 people interviewed, among them 47 employees of National Pedagogical Dragomanov University and 65 - 
students.

\section{RESULTS}

We analyzed the answers of 112 respondents, which can be represented by table 2 , which characterizes the level of cohesion as a whole on the respondents and presents data in the form of an arithmetic mean $(\bar{X})$ and standard deviation $(\sigma)$, which allows to see how distributed the values obtained with respect to the arithmetic mean and make conclusions.

Table 2. Results of the assessment of the social cohesion level in the university community

\begin{tabular}{lcc}
\hline \multicolumn{1}{c}{$\begin{array}{c}\text { Domains and } \\
\text { dimensions }\end{array}$} & $\begin{array}{c}\text { Arith. } \\
\text { mean }\end{array}$ & $\begin{array}{c}\text { Stand. } \\
\text { deviation }\end{array}$ \\
\hline $\begin{array}{l}\text { Social Networks } \\
\text { Trust in people }\end{array}$ & 3,71 & 0,71 \\
$\begin{array}{l}\text { Acceptance of } \\
\text { diversity }\end{array}$ & 4,81 & 0,67 \\
Social relations & $\mathbf{3 , 9 3}$ & 0,68 \\
\hline $\begin{array}{l}\text { Identification } \\
\text { Trust in institutions }\end{array}$ & 2,99 & $\mathbf{0 , 4 9}$ \\
$\begin{array}{l}\text { Perception of fairness } \\
\text { Connectedness }\end{array}$ & 2,76 & 0,79 \\
\hline $\begin{array}{l}\text { Solidarity and } \\
\text { helpfulness }\end{array}$ & 3,66 & 0,64 \\
$\begin{array}{l}\text { Respect for social } \\
\text { rules }\end{array}$ & 3,64 & 0,74 \\
$\begin{array}{l}\text { Civic participation } \\
\text { Focus on the } \\
\text { common good }\end{array}$ & 2,40 & 0,74 \\
\hline
\end{tabular}

By assessing the overall level of cohesion in the NPDU, we can see that the indicators of the domains are at the average level, and the domain "social relations" is almost closer to the higher than the average $(\bar{X}=$ 3.93). This means that on the whole, according to the model of social cohesion, in the National Pedagogic Dragomanov University we have a sufficient level of solidarity, which shows the greatest importance both among employees and students of social relations. Analyzing the dimensions themselves, we see that in the domain of "social relations" the highest level - above the average - has received the dimension "acceptance of diversity", that is, people with respect and tolerance towards those people who have other views, values, etc., that is very important in modern Ukrainian society, which is heading towards European values. In the second domain - "connectedness" - the greatest importance is the trust in institutions $(\bar{X}=3,43)$, and the least perception of fairness $(\bar{X}=2,76)$. This characterizes the high level of trust on the whole NPDU and below average of how people feel fair attitude to themselves in it.

In general, the "connectedness" domain has the lowest rate among others, but it still has an average value.

Turning to the domain of "focus on the common good" we see that solidarity and mutual assistance $(\bar{X}=3.67)$ and respect for social norms $(\bar{X}=3.64)$ are the most represented here. The lowest value was civic participation $(\bar{X}=2.40)$, which is more than 1 less than other indicators of this domain. It is also the smallest indicator of overall results.

The results of the evaluation of the domains of social cohesion are clearly shown in Figure 1.

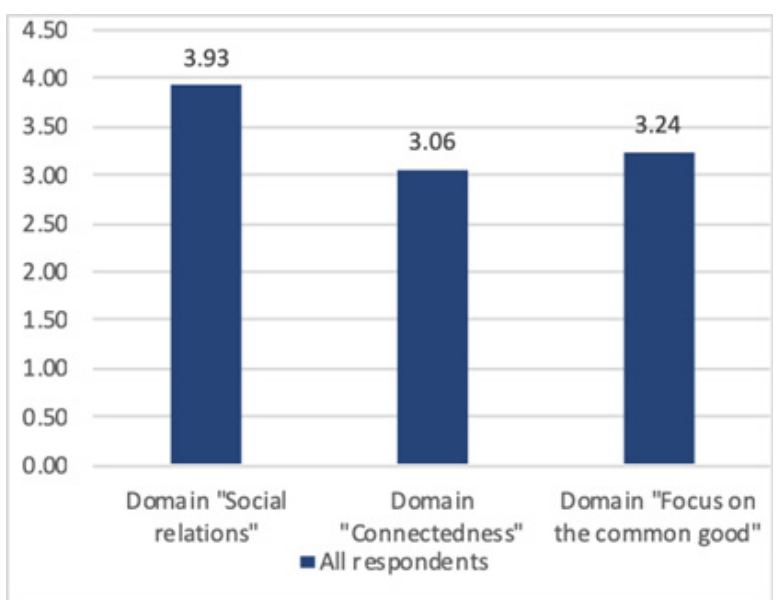

Figure 1. Results of social cohesion in the university community of NPDU by domains

To find out whether or not there is a difference between the groups of respondents, we will analyze the indicators that characterize the social cohesion of the employees of this university (47 people). The results are shown in the Table 3. It is evident that in general they do not differ in large measure from the indicators for the NPDU as a whole. For greater clarity, see Figures 2 and 3. 
Table 3. Results of the evaluation of the employees'cohesion in the university community of NPDU

\begin{tabular}{lcc}
\hline $\begin{array}{c}\text { Domains and } \\
\text { dimensions }\end{array}$ & Arith. mean & $\begin{array}{c}\text { Stand. } \\
\text { deviation }\end{array}$ \\
\hline $\begin{array}{l}\text { Social Networks } \\
\begin{array}{l}\text { Trust in people } \\
\text { Acceptance of } \\
\text { diversity }\end{array}\end{array}$ & 3,62 & 0,72 \\
Social relations & 4,42 & 0,68 \\
\hline $\begin{array}{l}\text { Identification } \\
\text { Trust in }\end{array}$ & $\mathbf{3 , 9 1}$ & 0,80 \\
$\begin{array}{l}\text { institutions } \\
\begin{array}{l}\text { Perception of } \\
\text { fairness }\end{array}\end{array}$ & 3,28 & 0,57 \\
Connectedness & 2,88 & 0,78 \\
\hline $\begin{array}{l}\text { Solidarity and } \\
\text { helpfulness } \\
\text { Respect for }\end{array}$ & 3,65 & 0,88 \\
social rules & 3,66 & 0,88 \\
$\begin{array}{l}\text { Civic } \\
\text { participation }\end{array}$ & 2,21 & 0,90 \\
$\begin{array}{l}\text { Focus on the } \\
\text { common good }\end{array}$ & $\mathbf{3 , 1 7}$ & $\mathbf{0 , 5 9}$ \\
\hline
\end{tabular}

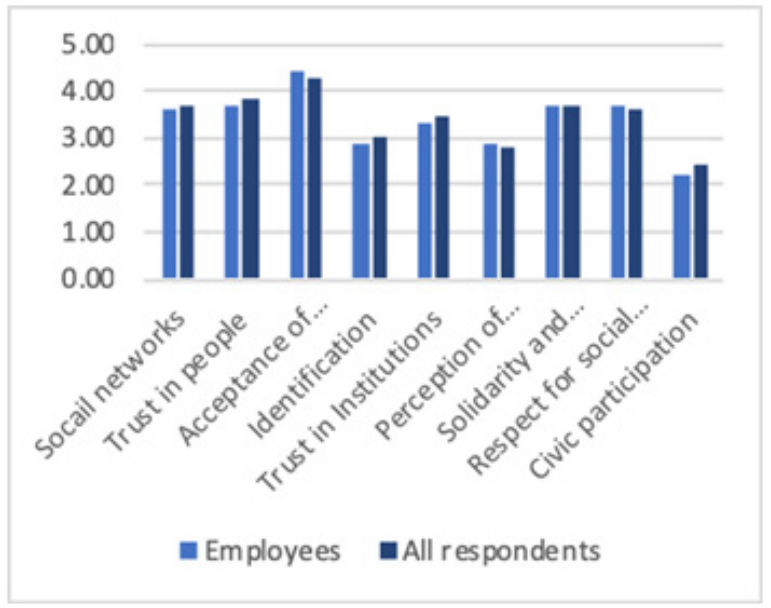

Figure 2. Comparison of social cohesion between all respondents and employees by dimensions

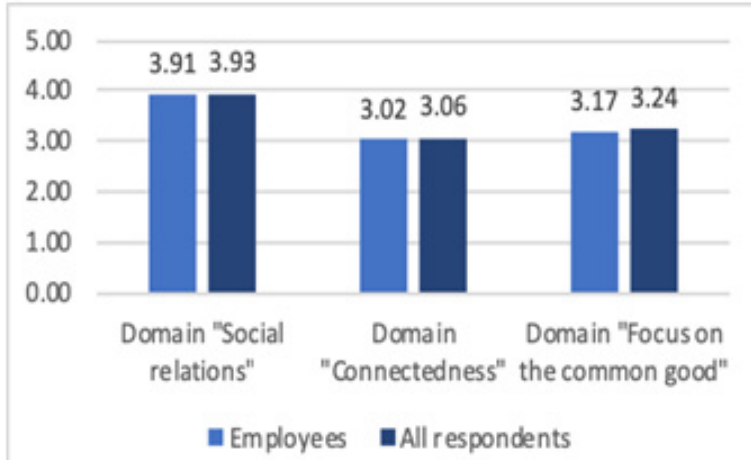

Figure 3. Comparison of social cohesion between all respondents and employees by domains

From the table and figures, we see that the levels of cohesion are almost the same. According to the domains from the employees, the data are approximately the same, that in general, relatively to the whole NPDU ( $\bar{X}$ $=3.91,3.02,3.17$, respectively). There is also no distinctive difference in dimensions: all the data though vary in numerical form, the qualitative differences do not reflect and are at the same level. Separately, attention should also be paid to the last dimension - Civic participation, which has an even lower value for employees $(\bar{X}=2,21)$, which is also less than 1 for other indicators of this domain.

Moving on to the analysis of the second group - students. In our representatives the number of students was 65 . The results of response processing are presented in Table 4 and in Figures 4.

Table 4. Results of the evaluation of the students' cohesion in the university community of NPDU

\begin{tabular}{lcc}
\hline \multicolumn{1}{c}{$\begin{array}{c}\text { Domains and } \\
\text { dimensions }\end{array}$} & $\begin{array}{c}\text { Domains } \\
\text { and } \\
\text { dimensions }\end{array}$ & $\begin{array}{c}\text { Domains } \\
\text { and } \\
\text { dimensions }\end{array}$ \\
\hline $\begin{array}{l}\text { Social Networks } \\
\text { Trust in people } \\
\text { Acceptance of } \\
\text { diversity }\end{array}$ & 3,77 & 0,69 \\
Social relations & $\mathbf{3 , 9 5}$ & 0,65 \\
\hline $\begin{array}{l}\text { Identification } \\
\begin{array}{l}\text { Trust in } \\
\text { institutions }\end{array}\end{array}$ & 3,05 & 0,55 \\
$\begin{array}{l}\text { Perception of } \\
\text { fairness }\end{array}$ & 3,55 & 0,78 \\
Connectedness & $\mathbf{3 , 0 9}$ & $\mathbf{0 , 3 9}$ \\
\hline $\begin{array}{l}\text { Solidarity and } \\
\text { helpfulness }\end{array}$ & 3,69 & 0,64 \\
$\begin{array}{l}\text { Respect for social } \\
\text { rules }\end{array}$ & 3,63 & 0,71 \\
$\begin{array}{l}\text { Civic } \\
\text { participation }\end{array}$ & 2,54 & 1,02 \\
$\begin{array}{l}\text { Focus on the } \\
\text { common good }\end{array}$ & $\mathbf{3 , 2 9}$ & $\mathbf{0 , 5 5}$ \\
\hline
\end{tabular}




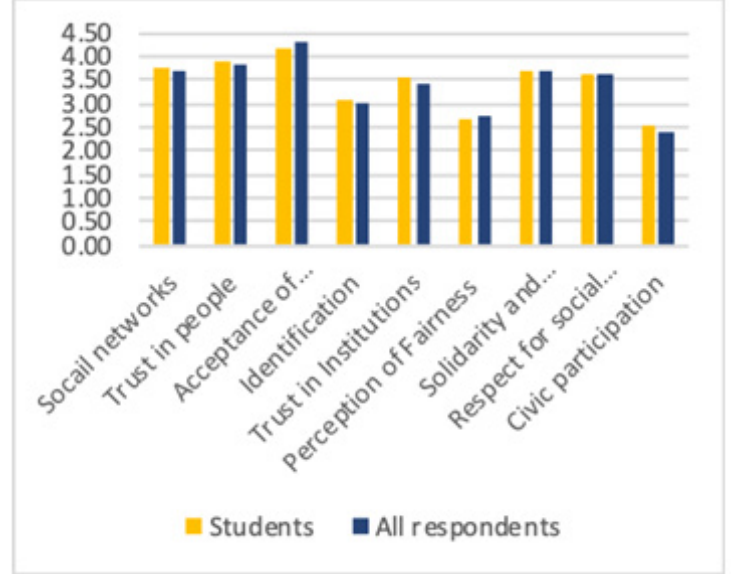

Figure 4. Comparison of social cohesion between all respondents and students by dimensions

The analysis of the results shows that the indicators for the spheres do not have a significant difference compared with the total for the whole community. All indicators are almost at the same levels that in general, according to the ROI, only the index of identification has a higher result than the average for the whole community - it reaches the average $(\bar{X}=3.05)$.

If we compare the rates between the students and the employees (Fig. 5, 6), then we see that, in general, the domains do not have a significant difference, only the focus on the common good differs more than other domains $(\bar{X}=3.17$ from employees and $\bar{X}=3.29$ for students). Dimensions analysis shows that this is achieved due to the greater participation of students in public life $(\bar{X}=2,54$ against $=$ 2,21 employees). In the other area there is no qualitative difference other than what has already been described.

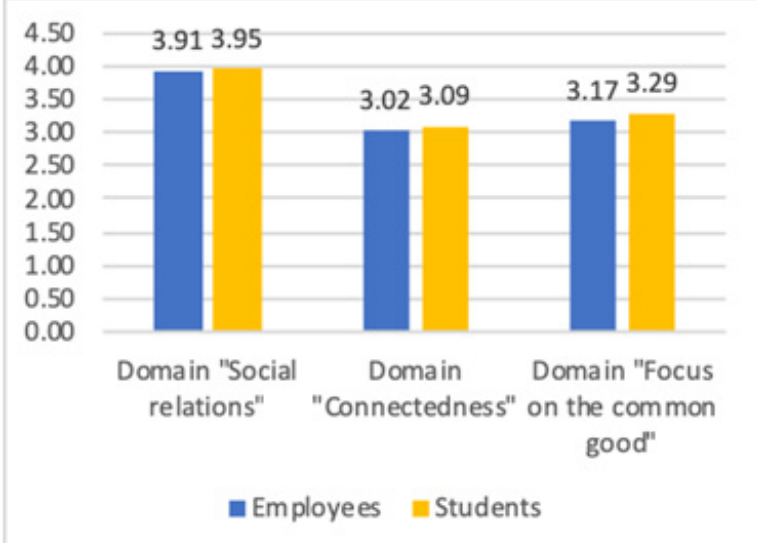

Figure 5. Comparison of social cohesion between employees and students by domains

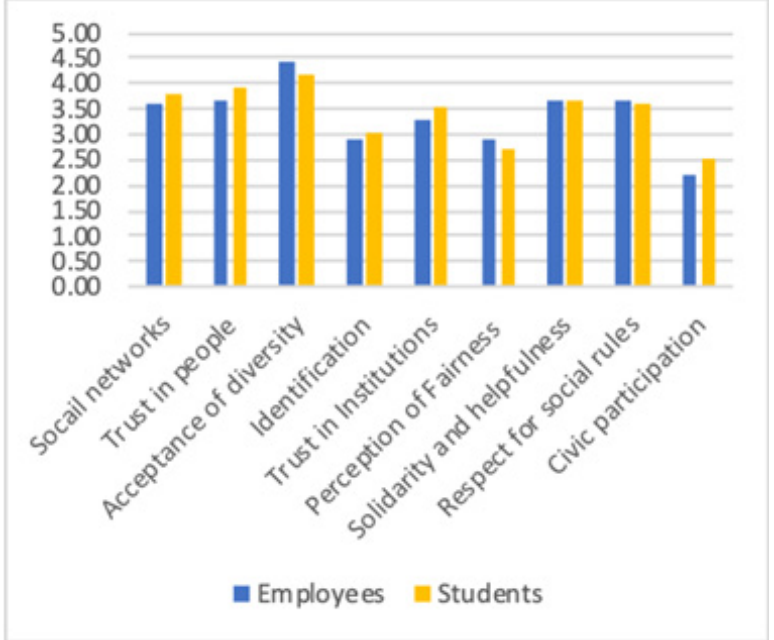

Figure 6. Comparison of social cohesion between employees and students by dimensions.

\section{DISCUSSIONS}

The obtained results make it possible to determine that, in general, the level of social cohesion in the university community of $\mathrm{Na}$ tional Pedagogical Dragomanov University is at the average level, with a slight fluctuation. But most employees and students focus on social relations, rather than on connectivity and orientation to the common good. The least people are aimed at public engagement, which, in the opinion of the authors, is due to low culture and lack of experience in civic activity in Ukraine. People do not understand how this contributes to the development of society and their own well-being.

There is no significant difference in the level of cohesion between the indicators for the university community of NPDU in general and employees in particular. Similarly, employees are more focused on social relations, less on connectivity and orientation towards common good. The average level of cohesion indicates a sufficient level. The higher than the average rate of acceptance of the other kind testifies that the employees of the NPDU with respect to people with other values, have tolerance to each other and can cooperate in this. In the second domain, the values of identification and perceptions of equity among employees are lower than the average, which means their low identification with the NPDU and the same level of perception of fairness in relation to them.

In general, the analysis of the results of the student response process showed that almost the whole level of cohesion coincides, 
besides connectedness, which characterizes their greater self-identification with the university than the employees. In another, the results can characterize students as those who believe in people, but less accept other values and differences, trust the institutions more, but perceive the attitude to them as fairness than employees, more than employees involved in public life.

We can further investigate these "weak points" in the social life of university community members - both students and employees. The next step is to compare social activity of students and employees in the external and internal social life of the educational community.

In the future the application of the research results would help to improve the social intelligence of educators, to improve their emotional competence skills, e. g. tolerance to diversity, intercultural dialog skills etc. It is presumed that the connected educational communities will enhance the level of social cohesion in education and society accordingly.

\section{CONCLUSIONS}

The role of education in social cohesion of communities is quite confident. But the phenomenon of social cohesion in education is not obvious and demands further investigations. Thus, the social cohesion in education could be considered from the focus of own connectedness of university community.

The Model of Social Cohesion by Bertelsmann Stiftung is very perspective for the research of the social cohesion in communities at the different levels - from cross-national to local. According to the above survey it could be applied at the level of educational community. In this concrete survey this model has been applied in the university community of National Pedagogical Dragomanov University (Kyiv, Ukraine). The aim of the research was to investigate the phenomenon of social cohesion in the education. The above research of social dimension of cognitive patterns of students and employees has been conducted in the university community to evaluate the real social cohesion level.

According to the obtained results we can maintain that the level of social cohesion in the university community of National Pedagogical Dragomanov University is quite sufficient, which positively characterizes the attitude of employees and students to each other, reflects their readiness for mutual assistance and re- spect, acceptance of differences and tolerance, respect for social norms. However, there are some areas where the level of social cohesion of the whole university's community can increase, and namely: achievement of indicators above average and high in all dimensions and domains. The data obtained for this research can form the basis for human resources management in the NPDU, so that employees are more likely to be treated fairly, identify themselves with the university, become more involved in public life both within and outside the university etc.

Speaking about cognitive aspects of social cohesion we lead to the successfulness in intrapersonal social communications and necessity to define the integral parameters of its development, monitoring and evaluation. This is the social (emotional) competence of social actors, in particular, educators. The social competence will lead to better quality of communication, tolerance to diversity, intercultural challenges etc. For educators as transformative actors for new generations the above key skills are strongly requested. Social cohesion development to be forced by some cognitive technologies. To find and implement them in educational community is a very complex and important task for educators as custodians and conductors of social values.

\section{ACKNOWLEDGEMENTS}

The authors are grateful to all participants of the research and to all of the editorial teem for their kind and professional assistance. The above research is the part of the project's implementation in the National Pedagogical Dragomanov University of Jean Monnet Module "Social Cohesion in Education and Governance: European Studies" (Erasmus + Program granted by European Commission).

\section{Conflict of interests}

The authors declare no conflict of interests.

\section{REFERENCES}

Alexiu, T. M., \& Sordé, T. (2011). How to turn difficulties into opportunities: Drawing from diversity to promote social cohesion. International Studies in Sociology of Education, 21(1), 49-62. https://doi.org/10.1080/09620214.2011.543852

Bertelsmann, S. (2013). Social Cohesion Radar: Measuring common ground. An international comparison of social cohesion. - Gütersloh: Bertelsmann Stiftung, pp. 76. 
Bondarenko, M., Babenko, S., \& Borovskiy, O. (2017). Social cohesion in Ukraine (The experience of application of Bertelsmann Stiftung method to European social survey data). Bulletin of Taras Shevchenko National University of Kyiv. Sociology. 8. 58-65. https://doi.org/10.17721/2413$7979 / 8.10$.

Dragolov, G., Ignácz, Z., Lorenz, J., Delhey, J., \& Boehnke, K. (2013). Social Cohesion Radar Measuring Common Ground: An international Comparison of Social Cohesion Methods Report. http://aei.pitt.edu/74134/1/Social_cohesion_radar.pdf

European Year for combating poverty and social exclusion (2010). Strategic Framework DocumentBrussels: European Commission, 2008. - 24 p. www.2010againstpoverty.europa.eu

Nesterova, M. (2019). EU intercultural dialog studies and social cohesion development. Ukraine- European Union: From Partnership Towards Association. The Ukrainian Yearbook of the European Integration Studies III/ - Lutsk, Teren, 2019 - p. $271-279$.

Nestorova, M. (2015). Когнитивистика: истоки, вызовы, перспективы [Cognitivistics: origins, challenges, perspectives]. Суми, Університетська книга. - 334 c. http://www.enpuir.npu.edu.ua/bitstream/123456789/19818/2/ Nesterova_2015.pdf

Roberts-Schweitzer, E., Greaney, V., \& Duer, K. (Eds.). (2006). Promoting Social Cohesion Through Education: Case Studies and Tools for Using Textbooks. The World Bank. http://hdl.handle. net/10986/6985

Sasson, I. (2018). Building a sustainable universitycommunity partnership: case study in science education. Studies in Higher Education, 1-15. https://doi.org/10.1080/03075079.2018.149641 0

Shamionov, R. M., \& Grigoryev, A. V. (2019). The image of socially active individual in the representations of student youth. International Journal of Cognitive Research in Science, Engineering and Education/IJCRSEE, 7(1), 15-20. https:// doi.org/10.5937/ijcrsee1901015S

Smith E. (2008). Using Secondary Data in Educational and Social Research / E. Smith. - Maidenhead: McGraw-Hill Education. - 210 p.

Social Cohesion and Education. https://education.stateuniversity.com/pages/2428/Social-CohesionEducation.html

Tawil, S., \& Harley, A. (2004). Education and identitybased conflict: Assessing curriculum policy for social and civic reconstruction. Education, conflict and social cohesion, 9. 